Potravinarstvo Slovak Journal of Food Sciences vol. 15, 2021, p. 1120-1127

https://doi.org/10.5219/1696

Received: 06 August 2021. Accepted: 15 October 2021. Available online: 28 October 2021 at www.potravinarstvo.com

\title{
THE EFFECT OF SOIL BIOSTIMULANT AGRIFUL ON THE SELECTED QUANTITATIVE AND QUALITATIVE PARAMETERS OF CARROT (DAUCUS CAROTA SUBSP. SATIVUS (HOFFM.) ARCANG.)
}

\author{
Júlia Fabianová, Alena Andrejiová, Miroslav Šlosár, Lenka Benzová, Alžbeta Hegedüsová
}

\begin{abstract}
The research task was focused on an important type of root vegetable - carrot (Daucus carota L.), cultivar 'Romance F1' (family: Apiaceae). The main goal was to verify the application of soil biostimulant Agriful (based on humic and fulvic acids) and its impact on the yield potential and quality of carrot roots. Nowadays, it is the common need to intensify and increase crop production because of the growing human population and look for environmentally friendly cultivation methods. In general, biostimulants are biologically based products and their purpose is to stimulate the natural nutritional processes in cultivated crops. In the realized experiment, Agriful (treatment of $5 \mathrm{~L} / 300 \mathrm{~L}$ water/ha) was applied twice per vegetation period by spraying over the pivot. The increase of average root weight after the application of Agriful was found, concretely about $+4.47 \%$ compared to the control variant. The higher root weight after Agriful application resulted in a higher total yield of carrot about $+2.84 \%$ compared to the control variant. The quality of consumable parts of carrots were evaluated based on the classification of roots into quality classes according to the valid standard for fresh carrot marketing (UNECE FFV-10). In the 'Extra class', there was an increase in the average yield after the application of Agriful about $+5.4 \%$; The average carrot yield in 'Class I' was decreased about $-1.0 \%$ and the root ratio in the 'Class II' decreased about $-1.9 \%$. The ratio of 'Non-standard' carrot roots was lower about $-2.5 \%$. Based on evaluating qualitative substance content (total carotenoids, refractometric dry matter), the positive influence of the effect of Agriful application was found. The content of total carotenoids was higher about $+8.7 \%$ compared to the control variant. The refractometric dry matter was higher about $+4.1 \%$ compared to the control variant. The obtained results can be used in further research on biostimulants and it is possible to create clear recommendations for using Agriful for small growers. It should be useful to verify these results in another vegetation period for recommendation to large-scale producers of carrots.
\end{abstract}

Keywords: biostimulant; carrot; yield; carotenoid; refractometric dry matter

\section{INTRODUCTION}

The carrot (Daucus carota L.) is one of the most popular root vegetables grown in the world. Worldwide, the average carrot production was 1.16 mil. tons within period $2015-$ 2018. China is the major carrot-producing country in the world (FAO, 2021). In Slovakia (Meravá, 2021), the situation in carrot growing has a growing character. In 2019, carrot production (14 292 tons) was more than multiple compared to 2017 (13 596 tons).

The consuming part of carrots is the storage root. The carrot root contains almost $88 \%$ water, $1 \%$ protein, $7 \%$ carbohydrates, $0.2 \%$ fat, and $3 \%$ fiber. Carbohydrates are represented mostly by simple sugars (sucrose, glucose, xylose, and fructose) with a negligible starch content (Arscott and Tanumihardjo, 2010). The carrot root is characterized by accumulating high amounts of carotenoids, mainly $\beta$-carotene (Oleszkiewicz et al., 2018; Tang, 2010). Further, carrot root is a good source of dietary fiber, minerals, and phytochemicals, e. g. vitamin C, phenolic compounds, polyacetylenes (Que et al., 2019; Ahmad et al., 2019).

With increasing of health awareness, carrot, or vegetables and fruits generally, becomes more attractive in the human diet due to their health-promoting effect and antioxidant activity. These effects are closely related to the strengthening of the human immune system and preventing degenerative diseases such as cardiovascular disease, stroke, cancer, skin diseases etc. (Sharma et al., 2012; Zaheer, 2017; Durec et al., 2019; Sabolová and Kouřimská, 2020).

Many agricultural research studies are currently focused on the application and importance of biostimulants preparations, which have been shown to have an impact on the quantitative and qualitative parameters of various fruits and vegetables (Adamec et al., 2019; Mikhov, 2012; Staneva, Akova and Kornov, 2020; Caruso et al., 2019; Soppelsa et al., 2018). 
Biostimulants are biologically based products, which stimulate plant physiological processes of nutrition in cultivated crops independently on their nutrient content. They offer a new approach to the regulation of natural processes, from which the response to stress factors, increased efficiency of fertilizer use, and total crop yield are the most important. Biostimulants are produced from a wide range of biological and inorganic materials. The main sources are microbial fermentation of animal or plant raw materials, live microbial cultures, macro and microscopic algae, protein hydrolysates, humic and fulvic substances, composts, manure, food, and industrial waste prepared by very specific industrial production processes (Yakhin et al., 2017).

Humic substances belong to the most established biostimulant used in agriculture because they have been shown to significantly improve plant growth (directly or indirectly), as well as improve soil properties and fertility (Nardi et al., 2016). One of the main results of their use is a better utilization of nutrient uptake (Jindo et al., 2020) and modulating of nutrient acquisition pathway of primary and secondary metabolism and hormonal and reactive oxygen balance (Vujinović et al., 2020). The use of humic substances relates to a positive impact on changes in the architecture in the root system (Canellas et al., 2015).

\section{Scientific hypothesis}

The effect of different soil biostimulants has been investigated on various crops, where its positive effect has been demonstrated. However, the root vegetables have not yet been well-examined and each year more and more biostimulant preparations are coming to the market. Thus, this study was focused on the hypothesis about the possible positive impact of Agriful application on the yield and quality of carrot roots.

\section{MATERIAL AND METHODOLOGY}

The field experiment was realized in 2020, in the company Agromačaj s.r.o. in the cadastral area of village Kostolná pri
Dunaji in The west of Slovakia. The carrot culture was grown in 20 hectares.

\section{Samples}

The carrot cultivar (Daucus carota subsp. Sativus) 'Romance F1' was used in the experiment. This variety is characterized by a homogeneous shape of the root, which is not inclinable to cracking. It is suitable for storage, direct consumption as well as processing. The seed producer indicates that the period of the growing season is 110 days. The carrot seed sowing was done on $5^{\text {th }}$ July 2020. The carrot root harvest was carried out on $9^{\text {th }}$ November 2020.

Within the experimental field, two variants were tested: C - control (without Agriful application); A - Agriful application. Five repeatings of each variant were diagonally arranged in carrot culture. The soil biostimulant Agriful is mainly based on humic and fulvic substances. Its composition is the following: humic acids (25\%), fulvic acids (25\%), $\mathrm{N}(4.5 \%), \mathrm{P}(1 \%), \mathrm{K}_{2} \mathrm{O}(1 \%)$, and other organic substances (45\%). The application dose of Agriful (5 L/300 L water/ha) was realized by spraying, as a part of irrigation, on $2^{\text {nd }}$ July 2020 and $14^{\text {th }}$ August 2020.

After harvest, the average weight of root, total yield, and quality classification of carrot roots was evaluated. The classification of carrot roots to the class quality was determined according to the standard UNECE FFV-10 concerning the marketing and commercial quality control of carrots. Within mentioned standard carrot quality classes are the following:

'Extra class' - carrot roots must be of superior quality. The roots must be smooth, fresh in appearance, regular in shape, free of fissures, free of bruises and cracks, free of damage due to frost, free of green or violet/purple tops.

'Class I' - carrot roots must be of good quality. The roots must be fresh in appearance. Slight defects may be allowed; however, defects must not effect on the general appearance of produce, the quality, the keeping quality, and presentation in the package. Slight defects are allowed in shape, coloring, healed cracks, slight cracks or fissures due to handling or washing, green or violet/purple tops up to the length of $1 \mathrm{~cm}$ for roots not exceeding $10 \mathrm{~cm}$ in length and $3 \mathrm{~cm}$ for other roots.

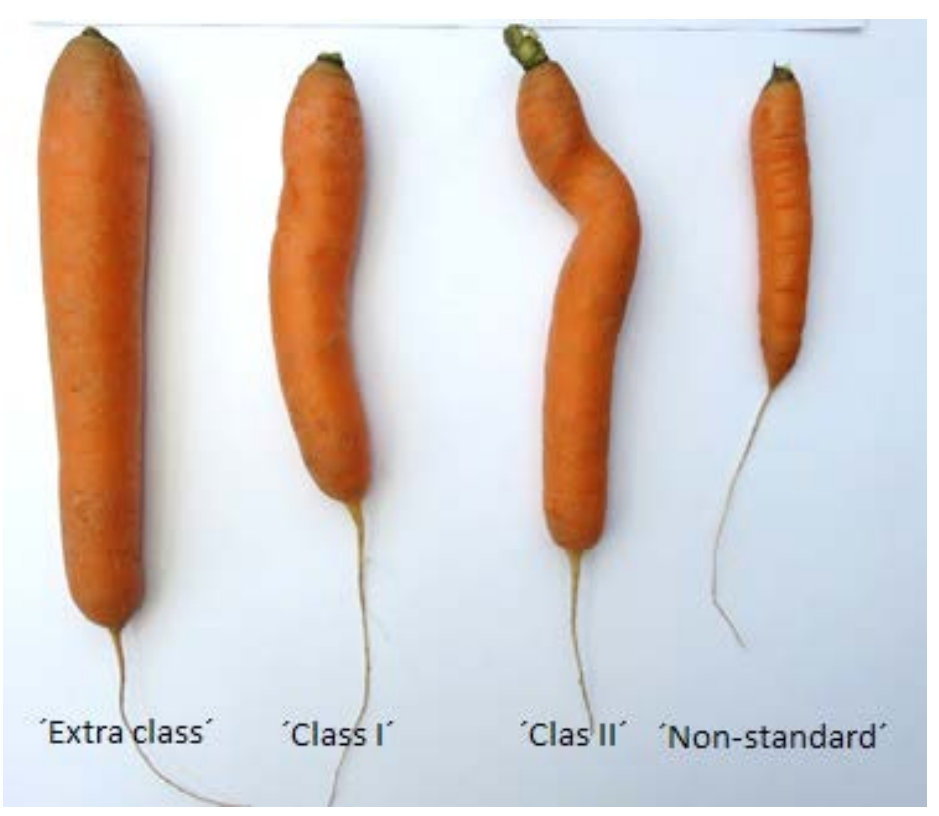

Figure 1 Sorting the consumer part according to quality classes based on the shape of the root. 
'Class II' - this class includes carrots which can not be classified in higher quality classes but the minimal criteria for carrot root must be filled. Root defects may be allowed, provided the carrots retain their essential characteristics as regards the quality, the keeping quality, and presentation: defects in shape, defects in coloring, healed cracks not reaching the heart, cracks or fissures due to handling or washing, green or violet/purple tops up to the length of $2 \mathrm{~cm}$ for roots not exceeding $10 \mathrm{~cm}$ in length and $3 \mathrm{~cm}$ for other roots.

\section{Laboratory Methods}

Qualitative laboratory analyses were realized at the Institute of Horticulture, the Slovak University of Agriculture in Nitra immediately after harvest. The content of total carotenoids and refractometric dry matter were analyzed in the fresh weight of carrot roots.

The average sample of tested variants for analyses was prepared from carrot roots of 'Extra class' or 'Class' I. All roots were quartered, and opposite quarters were used for qualitative analyses.

The analysis of total carotenoid content was realized by spectrophotometric measurement of substance absorbance in petroleum ether extract on the spectrophotometer PHARO 200 at the wavelength of $445 \mathrm{~nm}$. As an extraction reagent, acetone was used (Hegedüsová et al., 2018).

Within analysis of refractometric dry matter content, the juice from homogenized carrot was squeezed on the dry block of the digital hand-held refractometer (Kern ORD 45BM, Balingen, Germany). The value of soluble solids was directly read. Measurement was performed at room temperature according to Hegedüsová et al. (2018).

\section{Statistical Analysis}

Statistical analysis was performed by using of Microsoft Excel. The obtained results were evaluated by analysis of variance (ANOVA) and paired T-test at the significance level of $95 \%$.

\section{RESULTS AND DISCUSSION}

\section{The average weight of root (AW)}

The AW value of the carrot root in the control variant (C) was $59.50 \mathrm{~g}$. In the variant with Agriful (A), an increase of $\mathrm{AW}$ to the value of $62.16 \mathrm{~g}$ was found $(+4.5 \%$ compared to the control). The difference in AW of carrot roots between variant $C$ and $A$ was evaluated by multifactor analysis of variance (ANOVA) as statistically non-significant.

Due to the lack of experimental studies focused on the carrot and Agriful, gained results were confronted and compared with results of studies focused on the effect of Agriful in different crops. The field experiment focused on potatoes was realized by the company Organix s.r.o. (2017), distributor of the soil biostimulant Agriful in Slovakia. In the experiment, the increase of potato tuber AW from $79 \mathrm{~g}$ (control variant) to $88 \mathrm{~g}$ (Agriful variant) was found $(+11.4 \%)$. The field experiment oriented on the onion and Agriful was realized by Kandil, Sharief and Fathalla (2013). The AW of one onion bulb was increased from $120.1 \mathrm{~g}$ to $125.6 \mathrm{~g}(+4.6 \%)$ after Agriful application. Adamec et al. (2019) found that the average weight of bell pepper fruits (Capsicum annum L.) after Agriful application was higher about $+5.4 \%$ ('Esperansa F1') or $22.6 \%$ ('Kapirex F1') compared to the control variant. Results of this study indicate that genotype is also a very important factor influencing the reaction of plants to the application of Agriful, or humic and fulvic acids generally.

One of the main Agriful substances are humic (HA) and fulvic acids (FA) and their impact on the AW of the consumable part was monitored in experiments with carrot and some other crops. Alhariri and Boras (2020) tested the application of HA in the field experiment with carrots. The value of carrot root AW was increased from $45 \mathrm{~g}$ (control) to 70 or $111 \mathrm{~g}$, in dependency on the HA dose. El-Helaly (2018) realized experiment focused on the impact of HA and FA application on the AW of carrot roots. Its values were increased from $41 \mathrm{~g}$ (control) to 54 (HA) or $44 \mathrm{~g}$ (FA). Results of this study showed a stronger effect of HA compared to the carrot root AW than FA application. The beneficial effect of HA or FA application to AW was also found in studies focused on potato tubers (Suh, Yoo and Suh, 2014) or chili pepper fruits (Jan et al., 2020).

\section{Total carrot yield}

The total carrot yield was evaluated and converted to the area of 1 hectare (t.ha ${ }^{-1}$ ). The application of Agriful resulted in the increase of total carrot yield from 63.46 t.ha $^{-1}$ (C) 65.27 t.ha $^{-1}(\mathrm{~A})$. In percentage expression, this difference represented a value of $2.9 \%$ (Table 1 ). The difference in total yield of carrot roots between variants $\mathrm{C}$ and A variant was evaluated as statistically non-significant by using of multifactor analysis of variance (ANOVA).

Several studies have also shown that organic soil biostimulant Agriful tended to a higher yield of vegetable crops. In the experiment of company Organix s.r.o. (2014), potato tuber yield was increased from 59.2 t.ha $^{-1}$ (C) to 61.5 t.ha $^{-1}$ (A). After Agriful application, a higher yield of potatoes about $+3.89 \%$ was reached compared to the control variant. Kandil, Sharief and Fathalla (2013) found that Agriful application resulted in the increase of total onion bulb yield 36.7 t.ha $^{-1}$ to 38.5 t.ha ${ }^{-1}(+4.9 \%)$ compared to the control variant. The positive impact of Agriful on the crop yield was also presented in the study with bell pepper (Capsicum annum L.) realized by Adamec et al. (2019). In the variant with Agriful, authors found a higher yield of bell pepper about $+22 \%$ ('Esperansa F1') and 31.5\% ('Kapirex F1') compared to the control variant. On the contrary, Arnaoudov, Boteva and Dintcheva (2019) found a slight decrease of cucumber yield about $-0.4 \%$ after Agriful application, compared to the control, in the greenhouse experiment.

The effect of HA and FA, the main components of Agriful, was tested in experiments with carrots and other vegetable crops. El-Helaly (2018) found a different impact of HA and FA application on the total carrot yield. The application of HA resulted in the increase of total carrot yield from 13.93 t.ha ${ }^{-1}$ to 16.98 t.ha $^{-1}$ (average value of 4 cultivars) in comparison with control variant (+21.9\%). On the contrary, FA application (13.19 t.ha ${ }^{-1}$ ) was shown by a decrease of total carrot yield of about $-5.3 \%$ compared to the control (13.93 t.ha ${ }^{-1}$ ). Authors indicate that cultivar of carrot, or vegetables generally, is a very important factor determining the resulting effect of HA or FA acid application. Suh, Yoo and Suh (2014) tested effect of different doses of HA and FA on the total yield of potato tubers. The authors found statistically non-significant changes of total potato yield after the application of HA or FA as it was similarly found 
in this study with Agriful. The application of HA resulted in a slight increase of total potato yield from $+2.4 \%$ to $+3.6 \%$ compared to the control variant. From the aspect of FA application, a slight increase of total carrot yield was found in two variants with FA $(+1.0 \%$ or $+2.8 \%)$ and a slight decrease of carrot yield was found in one FA variant (2.5\%). Non-significant impact of FA application was also presented in the study with safflower (Moradi, Pasari and Fayyaz, 2017). On the contrary, Jan et al. (2020) found a statistically significant increase of yield after HA application in the field experiment with chilli pepper. In individual HA variants, fruit yield increase was ranged from $+7.3 \%$ to $+19.1 \%$ compared to the control variant. These results are inconsistent with results of other studies realized on red bean (Mohajerani et al., 2016), bell pepper (Karakurt et al., 2009; Maraei, Eliwa and Aly, 2019), strawberries (Shehata et al., 2011) of sugar beet (Wilczewski, Szczepanek and Wenda-Piesik, 2018), at which significant higher yield of crops was found after HA application. Results of these studies were showed the more significant influence of HA on the yield of grown crops.

\section{Quality classes of carrot roots}

The quality classes of roots were evaluated according to the valid marketing standard for fresh carrots (FFV-10), published by UNECE (2017). The total yield of carrot roots was divided into three quality classes: 'Extra class', 'Class I' and 'Class II'. Carrot roots, which do not meet the criteria of the above-mentioned class, are included in the class called 'Non-standard'. In Table 2, the percentage share of individual quality classes for both variants is mentioned. The percentage share of individual carrot quality classes in the control (C) variant was following: 'Extra class' $=60.4 \%$, 'Class I' $=19.8 \%$, 'Class II' $=2.5 \%$ and 'Non-standard' $=$ $17.3 \%$. In the variant with Agriful application (A), values of percentage share of carrot quality classes were following: 'Extra class' $=65.8 \%$, 'Class I' $=18.8 \%$, 'Class II' $=0.6 \%$ and 'Non-standard' $=14.8 \%$.

From gained data, the percentage difference between variants $\mathrm{C}$ and $\mathrm{A}$ for individual carrot quality classes were counted. Within the experiment, the share of 'Extra class' from total carrot yield was increased from $60.4 \%$ to $65.8 \%$ after Agriful application (+5.4\%). In other quality classes of carrot roots, its share was decreased about $-1.0 \%$ (Class I), $-1.9 \%$ (Class II) and $-5.5 \%$ (Non-standard). The difference of root share in 'Class II' between variants A and C were evaluated as statistically highly statistically significant. Differences of root share in other root quality classes between experimental variants were evaluated as statistically non-significant.

According to market requirements in the Slovak Republic, carrot quality classes 'Extra class' and 'Class I' are only marked as a marketable share. Carrot roots of the other two quality classes ('Class II' and 'Non-standard') are marked as a non-marketable share. From mentioned classification, the marketable share of carrot roots (Extra class + Class I) was increased from $80.2 \%$ (C) to $84.6 \%$ (A). On the contrary, the non-marketable carrot share was decreased from $19.8 \%$ (C) to $15.4 \%(A)$. The difference of marketable and nonmarketable share value between variants $\mathrm{C}$ and $\mathrm{A}$ was evaluated as statistically non-significant.

Gained results showed that the application of soil biostimulant Agriful has a positive effect on the higher share of marketable carrot roots. This finding is very interesting and important to producer from the aspect of economical profit.

The effect of Agriful to the marketable share of fruits was tested by Adamec et al. (2019) in the experiment with two bell pepper cultivars. Authors found more than 20\% increase in total fruit yield while only a minimum of fruits was classified in the 'Non-standard class'. In the average of two cultivars, an increase of 'Extra class' (+16\%) fruits and a decrease of 'Non-standard class' (-17.5\%) were found after Agriful application, compared to the control. The share of pepper fruits in 'Class I' and 'Class II' was relatively comparable between tested variants. Differences between quality classes were like in the study realised with Agriful and carrot.

El-Helaly (2018) tested effect of humic and fulvic acids, main components of Agriful, to the marketable yield of carrot roots. Different effect of HA and FA was found. The application of HA resulted in the increase of marketable carrot yield about $+20.0 \%$ compared to the control variant. On the contrary, application of FA was showed by lower, non-significant decrease of marketable carrot yield about $2.0 \%$. Results of this study were pointed on the more significant effect of $\mathrm{HA}$ as a part of biostimulant preparations, compared to the FA. Similar findings were presented in the study with potatoes (Suh, Yoo and Suh, 2014). Within mentioned study, HA application tended to the increase of marketable potato yield about 5.6\% compared to the control; on the contrary, no effect of FA application to the marketable yield of potato tubers was found.

\section{Total carotenoid content}

Total carotenoid content (TCC) in carrot roots from both experimental variants is mentioned in the Table 3 . After Agriful application, average TCC was at the level of 124.06 mg. $\mathrm{kg}^{-1}$ of fresh weight. In the control variant, TCC was 114.07 mg.kg-1 f.w. Value of TCC was increased after application of Agriful about 9.99 mg.kg-1 f. w. (+8.7\%) compared to the control variant. The difference between measured data was evaluated by a paired T-test to the mean value as a statistically non-significant. Adamec et al. (2019) studied the impact of Agriful on the TCC in fruits of two bell pepper (Capsicum annuum L.) cultivars. In the 'Esperansa F1' cultivar, a decrease of TCC was observed after application of Agriful (-17.03\% compared to the control). On the contrary, a positive effect of Agriful application to the value of TCC was found in the 'Kapirex F1' cultivar ( $+12.2 \%$ compared to the control).

There is lack of studies oriented on the effect of Agriful directly; thus, gained results could be compared with studies focused to the effect of humic (HA) and fulvic (FA) acids, which are the main components of Agriful, to the carotenoid content of vegetables. El-Helaly (2018) found different effect of HA and FA application to TCC in four cultivars of carrot. Average value of TCC was increased by application of FA $(+3.7 \%)$ and decreased by application of HA (23.6\%). On the contrary, Aminifard et al. (2012) found a positive effect of different HA and FA doses on the content of $\beta$-carotene, dominant carotenoid in bell pepper ('Red Chili') fruits. 
Table 1 Average weight of carrot root and total carrot yield.

\begin{tabular}{lcccc}
\hline Variant & $\begin{array}{c}\text { Average weight of carrot root } \\
(\mathbf{g})\end{array}$ & Rel. \%* $^{*}$ & $\begin{array}{c}\text { Total yield } \\
\text { (t.ha }^{-1} \text { ) }\end{array}$ & Rel. \%* $^{\text {\% }}$ \\
\hline C - control & $59.50 \pm 3.02^{\mathrm{a}}$ & 100 & $63.46 \pm 5.53^{\mathrm{a}}$ & 100 \\
A - Agriful & $62.16 \pm 3.09^{\mathrm{a}}$ & 104.47 & $65.27 \pm 3.54^{\mathrm{a}}$ & 102.85 \\
\hline
\end{tabular}

Note: Same letters (a) within the same column means statistically non-significant difference (at 95.0\% confidence level).

*Rel. \%. - relatively in \%.

Table 2 Classification of carrot roots into quality classes.

\begin{tabular}{lccc}
\hline \multicolumn{1}{c}{ Quality class } & $\begin{array}{c}\text { C-control } \\
(\mathbf{\%})\end{array}$ & $\begin{array}{c}\text { A- Agriful } \\
(\mathbf{\%})\end{array}$ & $\begin{array}{c}\text { Yield difference in individual classes (C-A) } \\
(\%)\end{array}$ \\
\hline Extra class & $60.4^{\mathrm{a}}$ & $65.8^{\mathrm{a}}$ & +5.4 \\
Class I & $19.8^{\mathrm{a}}$ & $18.8^{\mathrm{a}}$ & -1.0 \\
Class II & $2.5^{\mathrm{b}}$ & $0.6^{\mathrm{a}}$ & -1.9 \\
Non-standard & $17.3^{\mathrm{a}}$ & $14.8^{\mathrm{a}}$ & -2.5 \\
\hline
\end{tabular}

Note: Different letters (a; b) within the same column means statistically significant difference (at 95.0\% confidence level).

Table 3 Content of total carotenoids and refractometric dry matter.

\begin{tabular}{rcccc}
\hline Variant & $\begin{array}{c}\text { Total carotenoids } \\
\left(\mathbf{m g . k g}^{-1}\right)\end{array}$ & Rel. \%* & $\begin{array}{c}\text { Refractometric dry matter } \\
\left({ }^{\circ} \text { BRIX) }\right.\end{array}$ & Rel. \%* \\
\hline C - control & $114.07 \pm 18.51^{\mathrm{a}}$ & 100 & $9.84 \pm 0.54^{\mathrm{a}}$ & 100 \\
A - Agriful & $124.06 \pm 11.12^{\mathrm{a}}$ & 108.76 & $10.24 \pm 0.28^{\mathrm{a}}$ & 104.07 \\
\hline
\end{tabular}

Note: Same letters (a) within the same column means statistically non-significant difference (at 95.0\% confidence level). *Rel. \%. - relatively in \%.

Within this study, the increase of ß-carotene content, compared to the control, was ranged from $+10.7 \%$ to $+109.4 \%$ ( $+81.1 \%$ on average). In the variant with FA application, the increase of $\beta$-carotene content was ranged from $25.5 \%$ to $61.3 \%$ ( $+46.6 \%$ on average). Results of this study are focused on the significant effect of HA and FA from the aspect of carotenoid content in bell pepper fruits, or vegetables generally. A stronger effect of HA than FA was also detected. The slight increase of TCC after FA application was also shown and confirmed by another study with bell pepper (Akladious and Mohamed, 2018). On the contrary, a slight decrease of carotenoid due to the FA application was found in the study with wheat (Akcin, Akcin and Yildirim, 2020). Gholami et al. (2018) found that HA application was shown by an increase of total carotenoid content from $8.2 \mathrm{mg} . \mathrm{g}^{-1}$ (control) to $9.5 \mathrm{mg} . \mathrm{g}^{-1}$ $(+16.4 \%)$ in chicory. Results of mentioned studies were pointed to the strong effect of species and cultivar reaction to the application of HA or FA from the aspect of carotenoid content in consumable parts of grown crops.

\section{Refractometric dry matter}

Cejpek (2012) indicates that the method for analysis of refractometric dry matter (RDM) content is used for the determination of sugar content in fruit and vegetable juices, dairy products, and total concentration of monosaccharides and disaccharides in any solutions. According to Hegedüsová et al. (2018), RDM is defined as additive quantity expressing the content of dissolved substances, mostly sugars, in vegetable of fruit extracts. The Brix degree ( $\left.{ }^{\circ} \mathrm{BRIX}\right)$ is used as the unit of RDM content.

Within the realised study, an increase of RDM in carrot roots from $9.84{ }^{\circ} \mathrm{BRIX}$ (C - control) to $10.24{ }^{\circ} \mathrm{BRIX}$ (A Agriful) was reached $(+4.1 \%)$. The difference in $\mathrm{RDM}$ content between variants $\mathrm{C}$ and $\mathrm{A}$ was evaluated by multifactor analysis of variance (ANOVA) as statistically non-significant.

The effect of Agriful biostimulant on RDM content was also tested and demonstrated in the experiment with peach 'Glohaven' (Staneva, Akova and Kornov, 2020). After Agriful application, authors found an increase of RDM, compared to the control, about $+37.4 \%$, concretely from $8.3^{\circ} \mathrm{BRIX}(\mathrm{C})$ to $10.24^{\circ} \mathrm{BRIX}(\mathrm{A})$.

The effect of humic and fulvic acids, basic components of Agriful, was studied in the experiment with bell pepper 'Red Chili'. After HA application, an average value of RDM, dependent on the HA dose, was higher about $+5.1 \%$ in comparison with the control variant. The application of FA was shown by an increase of RDM in bell pepper about $+7.8 \%$ compared to the control. Results of this study were pointed to the positive impact of HA and FA application, both important Agriful substances, for increased accumulation of RDM, or sugars generally, in bell pepper fruits. This fact was also confirmed in other studies with different crops. Yildirim (2007) found the higher RDM after HA application in the experiment with tomato plants. The increase of its value, compared to the control, was ranged from $+11.2 \%$ to $18 \%$ in dependency on the HA dose and method of its application. Tejada and Gonzalez (2003) found an increase of RDM in the asparagus as an effect of foliar HA application. The non-significant increase of sugar content after HA application (+0.6\%) and FA application (1.6\%) was shown in experiments with sugar beet (Wilczewski, Szczepanek and Wenda-Piesik, 2018; Braziene, Paltanavicius and Avizienytè, 2021). On the contrary, Shehata et al. (2011) found a statistically nonsignificant decrease of RDM in strawberry fruits after HA application. 


\section{CONCLUSION}

The results obtained in this experimental work indicate that the application of biostimulant Agriful has a positive effect on important quantitative and qualitative parameters of carrots. The increase of total carrot yield (+2.9\%) and an average weight of roots $(+4.5 \%)$ was evaluated as statistically non-significant. The total yield of carrot roots can be classified into four quality groups based on UNECE standards. According to market requirements in the Slovak Republic, carrot quality classes 'Extra class' and 'Class I' are only marked as a marketable share. Carrot roots of the other two quality classes ('Class II' and 'Non-standard') are marked as a non-marketable share. The marketable share of carrot roots (Extra class + Class I) was increased, statistically non-significantly, from $80.2 \%$ (C) to $84.6 \%$ (A). This finding is very interesting and important to the producer from the aspect of economical profit. The content of most important bioactive substances in carrot carotenoids $(+8.7 \%)$ and content of refractometric dry matter (+4.1\%) were also increased, statistically nonsignificantly, after Agriful application. The obtained research results can be used in further research on biostimulants and it is possible to create a clear recommendation for using Agriful for small growers. It could be more profitable to apply Agriful on carrot plants more times ( 3 or 4 times) during the vegetation period for an expected higher increase of yield and quality of carrot roots. It should be useful to verify these results in another vegetation period for recommendation to large-scale producers of carrots.

\section{REFERENCES}

Adamec, S., Andrejiová A., Hegedűsová, A., Hegedűs, O., Musilová, J. 2019. Application effect of selected plant biostimulant on the quantitative and qualitative parameters of sweet pepper (Capsicum annum L.) in the organic farming system. International Multidisciplinary Scientific GeoConference: SGEM, vol. 19. Sofia : STEP92 Technology, p. 551-558. ISBN 978-619-7408-88-1.

Ahmad, T., Cawood, M., Iqbal, O., Ariño, A., Batool, A., Tariq, R. M. S., Azam, M., Akhtar, S. 2019. Phytochemicals in daucus carota and their health benefits-review article. Foods, vol. 8, no. 9, p. 424. https://doi.org/10.3390/foods8090424

Akcin, A., Akcin, T. A., Yildirim, C. 2020. Application of Fulvic Acid Modulates Photosynthetic Pigments and Malondialdehyde Content in Bread Wheat (Triticum aestivum cv. Ekiz) to Increase Resistance to Chromium Stress. International Journal of Agriculture and Biology, vol. 23, no. 1, p. 142-148. https://doi:10.17957/IJAB/15.1270

Akladious, S. A., Mohamed, H. I. 2018. Ameliorative effects of calcium nitrate and humic acid on the growth, yield component and biochemical attribute of pepper (Capsicum annuum) plants grown under salt stress. Scientia Horticulturae, vol. 236, p. 244-250. https://doi.org/10.1016/j.scienta.2018.03.047

Alhariri, A., Boras, M. 2020. Responses of seed germination and yield related traits to seed pretreatment and foliar spray of humic and amino acids compounds in carrot (Daucus carota L.). IJCS, vol. 8, no. 4, p. 26-30. https://doi.org/10.22271/chemi.2020.v8.i4a.10338

Aminifard, M., Aroiee, H., Azizi, M., Nemati, H., Jaafar, H. Z. E. 2012. Effect of Humic Acid on Antioxidant Activities and Fruit Quality of Hot Pepper (Capsicum annuum L.). Journal of
Herbs, Spices \& Medicinal Plants, vol. 18, no. 4, p. 360-369. https://doi.org/10.1080/10496475.2012.713905

Arnaoudov, B., Boteva, H., Dintcheva, T. 2019. Study of elements of integrated fertilizer systems in glasshouse cucumber. Trakia Journal of Sciences, vol. 17, no. 4, p. 375. https://doi:10.15547/tjs.2019.04.014

Arscott, S. A., Tanumihardjo, S. A. 2010. Carrots of many colors provide basic nutrition and bioavailable phytochemicals acting as a functional food. Comprehensive reviews in food science and food safety, vol. 9, no. 2, p. 223-239. https://doi.org/10.1111/j.1541-4337.2009.00103.x

Braziene, Z., Paltanavicius, V., Avizienyte, D. 2021. The influence of fulvic acid on spring cereals and sugar beets seed germination and plant productivity. Environmental Research, vol. 195, p. 110824. https://doi.org/10.1016/j.envres.2021.110824

Canellas, L. P., Olivares, F. L., Aguiar, N. O., Jones, D. L., Nebbioso, A., Mazzei, P., Piccolo, A. 2015. Humic and fulvic acids as biostimulants in horticulture. Scientia horticulturae, vol 196, $15-27$. https://doi.org/10.1016/j.scienta.2015.09.013

Caruso, G., De Pascale, S., Cozzolino, E., Cuciniello, A., Cenvinzo, V., Bonini, P., Colla, G., Rouphael, Y. 2019. Yield and nutritional quality of Vesuvian Piennolo tomato PDO as affected by farming system and biostimulant application. Agronomy, vol. 9, no. 9, p. 505. https://doi.org/10.3390/agronomy9090505

Cejpek, K. 2012. Analysis of food and natural products: Determination of carbohydrates in foodstuffs. Prague : Institute of Chemical Technology. Available at: https://web.vscht.cz/ kohoutkj/ENG/LAPP_ANGL_LC2_201 2.pdf.

Durec, J., Kozelová, D., Matejková, E., Fikselová, M., Jakabová, S. 2019. Fruit as a source of antioxidants and trends in its consumption. Potravinarstvo, vol. 13, no.1, p. 251-257. https://doi.org/10.5219/1042

El-Helaly, M. A. 2018. Effect of foliar application of humic and fulvic acids on yield and its components of some carrot (Daucus carota 1.) cultivars. Journal of Horticultural Science \& Ornamental Plants, vol. 10, no. 3, p. 159-166. https://doi.10.5829/idosi.jhsop.2018.159.166

FAO. 2021. Crops. Available at: http://www.fao.org/faostat/en/\#data/QC.

Gholami, H., Ghani, A., Raouf Fard, F., Saharkhiza, M. J., Hazrati, H. 2018. Changes in photosynthetic pigments and uptake of some soil elements by chicory supplied with organic fertilizers. Acta Ecologica Sinica, vol. 39, no. 3, p. 250-269. https://doi.10.1016/j.chnaes.2018.09.003

Hegedüsová, A., Šlosár, M., Mezeyová, I., Hegedüs, O., Andrejiová, A., Szarka, K. 2018. Methods for estimation of selected biologically active substances. Nitra: Slovak University of Agriculture. 95 p. ISBN 978-80-552-1928-8. Available at: http://ves.uniag.sk/files/pdf/uek48oryzs3bxggx1n1rmcg92gj0 nu.pdf.

Jan, J. A., Nabi, G., Khan, M., Ahmad, S., Shah, P. S., Hussain, S., Sehrish. 2020. Foliar Application of Humic Acid Improves Growth and Yield of Chilli (Capsicum annum L.) Varieties. Pakistan Journal of Agricultural Research, vol. 33, no.3, $\quad$ p. 461. https://doi.org/10.17582/journal.pjar/2020/33.3.461.472

Jindo, K., Olivares, F. L., Da Paixão Malcher, D. J., SánchezMonedero, M. A., Kempenaar, C. Canellas, L. P. 2020. From Lab to Field: Role of Humic Substances Under Open-Field and Greenhouse Conditions 
as Biostimulant and Biocontrol Agent. Frontiers in Plant Science, vol. $11, \quad$ p. 426. http://doi.org/10.3389/fpls.2020.00426

Kandil, A. A., Sharief, A. E., Fathalla, F. H. 2013. Onion yield as affected by foliar application with amino and humic acids under nitrogen fertilizer levels. Crop Production, vol. 2, no. 2 2, p. 62-72. https://www.researchgate.net/publication/288008698_Onion_ yield_as_affected_by_foliar_application_with_amino_and_hu mic_acids_under_nitrogen_fertilizer_levels.

Karakurt, Y., Unlu, H., Unlu, H., Padem, H. 2009. The influence of foliar and soil fertilization of humic acid on yield and quality of pepper. Acta Agriculturae Scandinavica Section B-Soil and Plant Science, vol. 59, no. 3, p. 233-237. https://doi.org/10.1080/09064710802022952

Maraei, R., Eliwa, N., Aly, A. 2019. Use of some biostimulants to improve the growth and chemical constituents of sweet pepper. Potravinárstvo: Slovak Journal of Food Sciences, vol. 13, no. 1, p- 553-561. https://doi.org/10.5219/1131

Meravá, E. 2021. Situation and outlook report - Fruit and vegetables (Situačná a výhl’adová správa - Ovocie a zelenina). Bratislava: VÚEPP. ISSN 13 38-8002. Available at: https://www.vuepp.sk/dokumenty/komodity/2021/Ovocie_zel enina_2021_07_v2.pdf.

Mikhov, M. 2012. Influence of bioproducts on energy productivity of field tomatoes. Agricultural Engineering (Bulgaria), vol. 49, no. 1. p. 5-13. https://agris.fao.org/agrissearch/search.do?recordID=BG2012000524.

Mohajerani, S., Fazel, M. A., Madani, H., Lak, S., Modhej, A. 2016. Effect of the foliar application of humic acid on red bean cultivars (Phaseolus vulgaris L.). Journal of Experimental Biology and Agricultural Sciences, vol. 4, no. 5, p. 519-524. https://doi.org/10.18006/2016.4(5).519.524

Moradi, P., Pasari, B., Fayyaz, F. 2017. The effects of fulvic acid application on seed and oil yield of safflower cultivars. Journal of Central European Agriculture, vol. 18, no. 3. https://doi.org/10.5513/jcea.v18i3.5615

Nardi, S., Pizzeghello, D., Schiavon, M., Ertani, A. 2016. Plant biostimulants: physiological responses induced by protein hydrolyzed-based products and humic substances in plant metabolism. Scientia Agricola, vol. 73, p. 18-23. https://doi.org/10.1590/0103-9016-2015-0006

Oleszkiewicz, T., Klimek-Chodacka, M., Milewska-Hendel, A., Zubko, M., Stróż, D., Kurczyńska, E., Boba, A., Szopa, J., Baranski, R. 2018. Unique chromoplast organisation and carotenoid gene expression in carotenoid-rich carrot callus. Planta, vol. 248, p. 1455-147. https://doi.org/10.1007/s00425018-2988-5

Organix. 2014. Agriful. Available at: https://organix.sk/wpcontent/uploads/2018/02/Agriful.pdf.

Organix. 2017. Agriful. Available at: https://organix.sk/wpcontent/uploads/2018/02/Agriful.pdf.

Que, F., Hou, X. L., Wang, G. L., Xu, Z. S., Tan, G. F., Li, T., Wang, Y. H., Khadr, A., Xiong, A. S. 2019. Advances in research on the carrot, an important root vegetable in the Apiaceae family. Hortic Res, vol 6, no. 69. https://doi.org/10.1038/s41438-019-0150-6

Sabolová, M., Kouřimská, L. 2020. Vitamin C and nitrates contents in fruit and vegetable from farmer's markets. Slovak Journal of Food Sciences, vol. 14. https://doi.org/10.5219/1347

Sharma, K. D., Karki, S., Thakur, N. S., Attri, S. 2012. Chemical composition, functional properties and processing of carrot-a review. J Food Sci Technol, vol. 49, p. 22-32. https://doi.org/10.1007/s13197-011-0310-7
Shehata, S., Gharib, S. A., El-Mogy, M. M., Gawad, A., Shalaby, E. A. 2011. Influence of compost, amino and humic acids on the growth, yield and chemical parameters of strawberries. Journal of Medicinal Plants Research, vol. 5, no. 11, p. 2304-2308. https://doi.org/10.5897/JMPR.9000789

Soppelsa, S., Kelderer, M., Casera, C., Bassi, M., Robatscher, P., Andreotti, C. 2018. Use of biostimulants for organic apple production: effects on tree growth, yield, and fruit quality at harvest and during storage. Frontiers in plant $\begin{array}{lllll}\text { science, } & \text { vol. } & 9, & \text { p. } & 1342 .\end{array}$ https://doi.org/10.3390/agronomy9090483

Staneva, I., Akova, V., Kornov, G. 2020. The influence of some bioproducts on the yield and chemical composition of the peaches under the conditions of integrated plant production. Scientifics papers. Series B, Horticulture, vol. 64, no. 2,, p. 113-119.

http://horticulturejournal.usamv.ro/pdf/2020/issue_2/vol2020 _2.pdf.

Suh, H. Y., Yoo, K. S., Suh, S. G. 2014. Tuber growth and quality of potato (Solanum tuberosum L.) as affected by foliar or soil application of fulvic and humic acids. Horticulture. Environment, and Biotechnology, vol. 55, no. 3, p. 183-189. https://doi.org/10.1007/s13580-014-0005-x

Tang, G. 2010. Bioconversion of dietary provitamin A carotenoids to vitamin A in humans. The American Journal of Clinical Nutrition, vol. 91, no. 5, p. 1468S-1473S. https://doi.org/10.3945/ajcn.2010.28674G

Tejada, M., Gonzalez, J. L. 2003. Influence of foliar fertilization with amino acids and humic acids on productivity and quality of asparagus. Biological agriculture \& horticulture, vol. 21, no. 3, p. 277-291. https://doi.org/10.1080/01448765.2003.9755270

UNECE. 2017. UNECE standard FFV-10 concerning the marketing and commercial quality control of carrots. Available at: https://unece.org/fileadmin/DAM/trade/agr/standard/fresh/FF V-Std/English/10_Carrots.pdf.

Vujinović, T., Zanin, L., Venuti, S., Contin, M., Ceccon, P., Tomasi, N., Pinton, R., Cesco, S., De Nobili, M. 2020. Biostimulant action of dissolved humic substances from a conventionally and an organically managed soil on nitrate acquisition in maize plants. Frontiers in plant science, vol. 10, p. 1652. https://doi.org/10.3389/fpls.2019.01652

Wilczewski, E., Szczepanek, M., Wenda-Piesik, A. 2018. Response of sugar beet to humic substances and foliar fertilization with potassium. Journal of Central European Agriculture, vol. 19, no. https://doi.org/10.5513/jcea.v18i5.6638

Yakhin, O. I., Lubyanov, A. A., Yakhin, I. A., Brown, P. H. 2017. Biostimulants in plant science: A global perspective. Frontiers in plant science, vol. 7, p. 2049. https://doi.org/10.3389/fpls.2016.02049

Yildirim, E. 2007. Foliar and soil fertilization of humic acid affect productivity and quality of tomato. Acta Agriculturae Scandinavica Section B-Soil and Plant Science, vol. 57, no. 2, p. 182-186. https://doi.org/10.1080/09064710600813107

Zaheer, K. 2017. Hen egg carotenoids (lutein and zeaxanthin) and nutritional impacts on human health: a review. CyTA Journal of Food, vol. 15, no. 3, p. 474-487. https://doi.org/10.1080/19476337.2016.1266033

\section{Funds:}

This work was supported by grant KEGA 018SPU$4 / 2020$. 


\section{Acknowledgments:}

We would like to thank you to companies Agromačaj s.r.o. and Organix s.r.o. for their participation on the experiment.

\section{Conflict of Interest:}

The authors declare no conflict of interest.

\section{Ethical Statement:}

This article does not contain any studies that would require an ethical statement.

\section{Contact Address:}

*Ing. Júlia Fabianová, the Slovak University of Agriculture in Nitra, Horticulture and Landscape Engineering Faculty, Institute of Horticulture, Tr. A. Hlinku 2, 94976 Nitra, Slovak Republic, Tel.: +421917373587,

E-mail: xbedrichova@uniag.sk

ORCID: https://orcid.org/0000-0002-6756-472X

Ing. Alena Andrejiová, the Slovak University of Agriculture in Nitra, Horticulture and Landscape Engineering Faculty, Department of Vegetable Production, Tr. A. Hlinku 2, 94976 Nitra, Slovakia, Tel.:+421 37641 4247,

E-mail: alena.andrejiova@uniag.sk

ORCID: https://orcid.org/0000-0001-5484-440X
Ing. Miroslav Šlosár, the Slovak University of Agriculture in Nitra, Horticulture and Landscape Engineering Faculty, Institute of Horticulture, Tr. A. Hlinku 2, 94976 Nitra, Slovakia, Tel.: +421376414261,

E-mail: miroslav.slosar@uniag.sk

ORCID: https://orcid.org/0000-0001-8692-405X

Alžbeta Hegedüsová, the Slovak University of Agriculture in Nitra, Horticulture and Landscape Engineering Faculty, Institute of Horticulture, Tr. A. Hlinku 2, 94976 Nitra, Slovakia, Tel.: +421376414712,

E-mail: alzbeta.hegedusova@uniag.sk

ORCID: https://orcid.org/0000-0001-6994-1077

Lenka Benzová, the Slovak University of Agriculture in Nitra, Horticulture and Landscape Engineering Faculty, Institute of Horticulture, Tr. A. Hlinku 2, 94976 Nitra, Slovakia,

E-mail: xbenzova@uniag.sk

Corresponding author: * 